\title{
Population dynamics of the philometrid nematode Margolisianum bulbosum in the southern flounder Paralichthys lethostigma (Pisces: Paralichthyidae) in South Carolina, USA
}

\author{
Claire Golléty ${ }^{1}$, Vincent A. Connors ${ }^{2}$, Ann M. Adams ${ }^{3}$, William A. Roumillat ${ }^{4}$, \\ Isaure de Buron ${ }^{1, *}$
}

\author{
${ }^{1}$ Department of Biology, College of Charleston, 58 Coming Street, Charleston, South Carolina 29401, USA \\ ${ }^{2}$ Department of Biology, University of South Carolina-Upstate, 800 University Way, Spartanburg, South Carolina 29301, USA \\ ${ }^{3}$ US Food and Drug Administration, Kansas City District Laboratory, Lenexa, Kansas 66214, USA \\ ${ }^{4}$ Department of Natural Resources, PO Box 12559, Fort Johnson Road, Charleston, South Carolina 29422, USA
}

\begin{abstract}
This is the first report of the philometrid nematode Margolisianum bulbosum Blaylock and Overstreet, 1999 from the southern flounder Paralichthys lethostigma on the east coast of the USA. Observation of adult female worms was used as an indication of the parasite's presence in the fish. Adult females were found only in P. lethostigma $>150 \mathrm{~mm}$ total length. The overall prevalence was $74 \%$, with a mean intensity of 5 female nematodes per parasitized fish. Infected flounders were found throughout the year with a statistically significant decrease in intensity in the winter months. Neither salinity, water temperature, fish gender nor fish age were found to influence either prevalence or intensity of infection in the flounder. While larvigerous (gravid) females were found throughout the year, the significant decrease in their occurrence during the summer through fall, in concert with an observed decrease in intensity of infection during the winter, indicated that the life cycle of this philometrid species is likely to be annual.
\end{abstract}

KEY WORDS: Nematode $\cdot$ Philometridae $\cdot$ Population dynamics $\cdot$ Southern flounder

\section{INTRODUCTION}

The southern flounder Paralichthys lethostigma is a fish of mariculture interest (Watanabe et al. 1998, Smith \& Denson 2000, Lee \& Ostrowski 2001). Because it is also of commercial and recreational importance (Wenner et al. 1990, Waters 1999, Moustakas et al. 2004), health assessment of this species is particularly valuable. Until the present report from the South Carolina (SC) coast, the philometrid nematode Margolisianum bulbosum Blaylock and Overstreet, 1999 has only been reported from P. lethostigma in the Mississippi Sound of the Gulf of Mexico, where it was noted to occur irregularly (Overstreet \& Edwards 1976, Blaylock \& Overstreet 1999). Significantly, very little is known about this potentially pathogenic nematode, since much of its biology and ecology remains an enigma and nothing is known about the long-term impact of this parasite on its host's population. Adult female $M$. bulbosum are found in various microhabitats in the buccal and gill cavities of the host and are the only conspicuous life cycle stages in the fish. Males of this species are very small and are found between muscle fibers in the head (Blaylock \& Overstreet 1999) or occasionally coupled with a female in buccal cysts (Blaylock \& Overstreet 1999 and authors' pers. obs.). Most studies on philometrid nematodes have been related to the development and life cycle of the parasites (for review see Anderson 2000), but little or no work has focused on their population dynamics (e.g. 
Wang 2002). Because mariculture broodstocks are taken from the wild in South Carolina (Smith et al. 1999) it is deemed important to understand the life cycle and seasonal occurrence of $M$. bulbosum in order to accurately gauge the potential impact of this parasite on local mariculture efforts. The purpose of this work was to determine the prevalence and intensity of M. bulbosum in estuarine systems on the coast of South Carolina in order to provide information pertinent to understanding the life cycle and biology of this parasite. A year-long study of the population dynamics of M. bulbosum adult females was therefore performed in various estuarine systems on the coast of South Carolina in order to obtain basic data on the population dynamics and life cycle of this parasite.

\section{MATERIALS AND METHODS}

Because male Margolisianum bulbosum Blaylock and Overstreet, 1999 are only seldom found and therefore not a reliable indication of infection by this species, this study was based on the observation of female worms alone. For each fish, females were tallied and their stage of maturity recorded as ovigerous (subgravid) females $(\mathrm{O})$, which had their uterus filled with eggs; larvigerous (gravid) females (L), which had their uterus packed with larvae; ovi-larvigerous females (O/L), which had both eggs and larvae in their uterus.
Southern flounders $(\mathrm{n}=170)$ ranging in size from 25 to $582 \mathrm{~mm}$ in total length (TL) were collected from July 2002 through June 2003 using electrofishing, trammel netting, or trawling, depending on depth, season and salinity at the collection sites. Fish were collected from offshore locations and from 10 sites throughout South Carolina estuarine systems (see Fig. 1). Salinity and water temperature were recorded at each site. For each fish the TL and sex were recorded and otoliths collected for age determination. Flounders were divided into the following 4 size classes based upon TL: $<150,150$ to 299,300 to 449 , and 450 to $600 \mathrm{~mm}$. Because flounders in the smallest category $(<150 \mathrm{~mm}$ TL) were never found to harbor adult females, all statistical analyses were performed on larger fish to avoid biasing the results. For analytical purposes, the yearlong sampling effort was divided into six 2 mo long periods ('waves') within which a minimum of 7 flounders of random sizes were dissected. Water temperatures were grouped into 4 categories reflecting seasonal water temperatures in the estuarine systems: $<15,16$ to 20,21 to 25 , and $>25^{\circ} \mathrm{C}$. Salinities were grouped into 3 categories: oligohaline (0 to 5 salinity), mesohaline (5.1 to 18 salinity), polyhaline and euryhaline (>18.1 salinity). Prevalences (percent of parasitized fish) and mean intensities (number of female nematodes per parasitized fish) were calculated and analyzed relative to size, age and gender of the flounder as well as seasonality and water temperature and

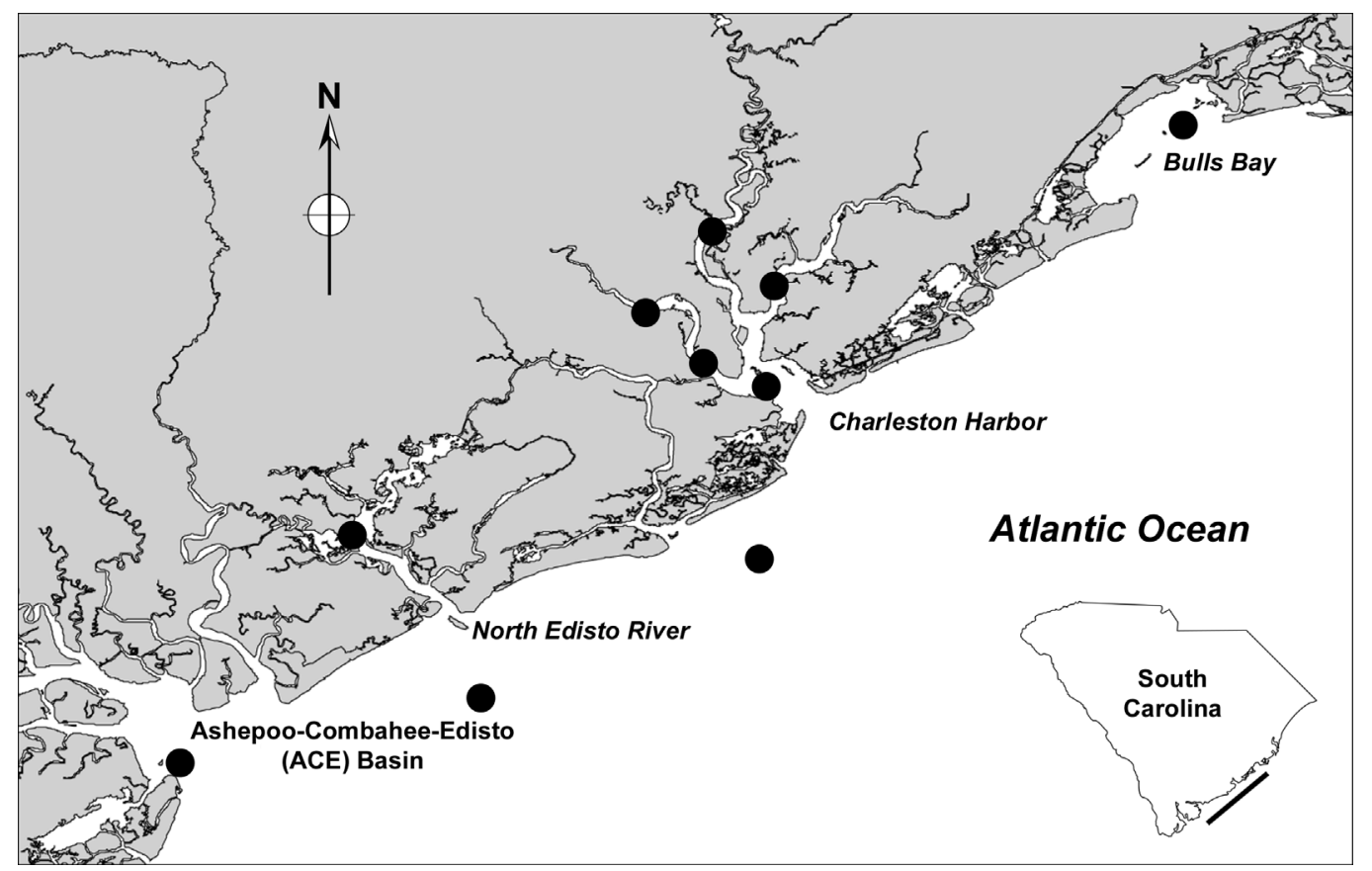

Fig. 1. Estuarine systems on the coast of South Carolina indicating sites of capture lethostigma infected with Margolisianum bulbosum 
salinity at capture. Further, the percentage of each of the 3 developmental stages of the female nematode $(\mathrm{O}$, $\mathrm{L}$ and $\mathrm{O} / \mathrm{L}$ ) was calculated for each wave to assess changes in the female nematode population over time. Prevalences and mean intensities were analyzed using the G-test of heterogeneity (Sokal \& Rohlf 1981) and the Kruskal-Wallis test (SYSTAT), respectively, with $\alpha$ $=0.05$. All terms were used according to definitions set by Bush et al. (1997) and data are expressed as means $\pm \mathrm{SE}$.

\section{RESULTS AND DISCUSSION}

Flounders at all sampling sites were found to be infected with Margolisianum bulbosum, indicating that this worm is widely distributed within SC estuarine systems (Fig. 1). The overall prevalence of the parasite was $62.35 \%$, while the overall intensity was 5 $( \pm 1)$ adult females. However, because flounders in the smallest size class $(<150 \mathrm{~mm} \mathrm{TL})$ were never found to harbor adult females (Fig. 2), exclusion of fish $<150 \mathrm{~mm}$ TL from the analysis raised the prevalence value to $74 \%$. The threshold of infection with adult
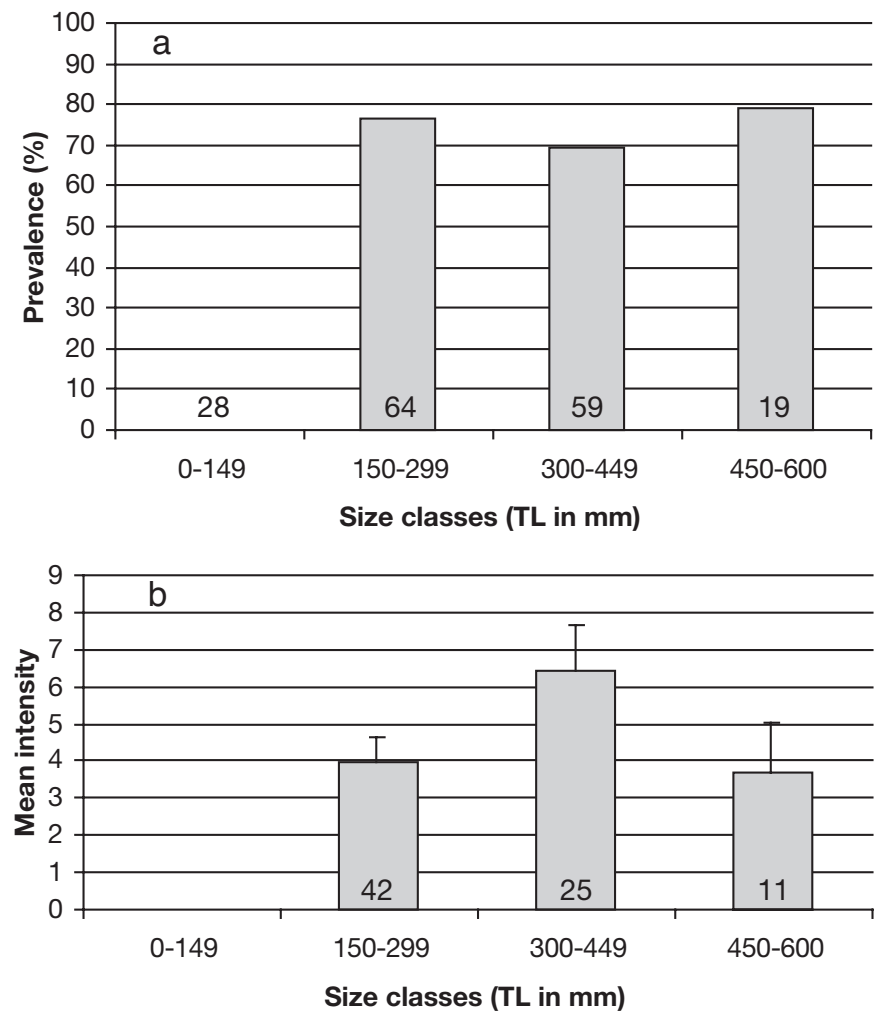

Fig. 2. Southern flounder Paralichthys lethostigma infected by adult female Margolisianum bulbosum. (a) Prevalence and (b) mean intensity (female nematodes per parasitized fish) of infection as a function of size class of fish (total length, TL). Numbers inside bars are sample sizes
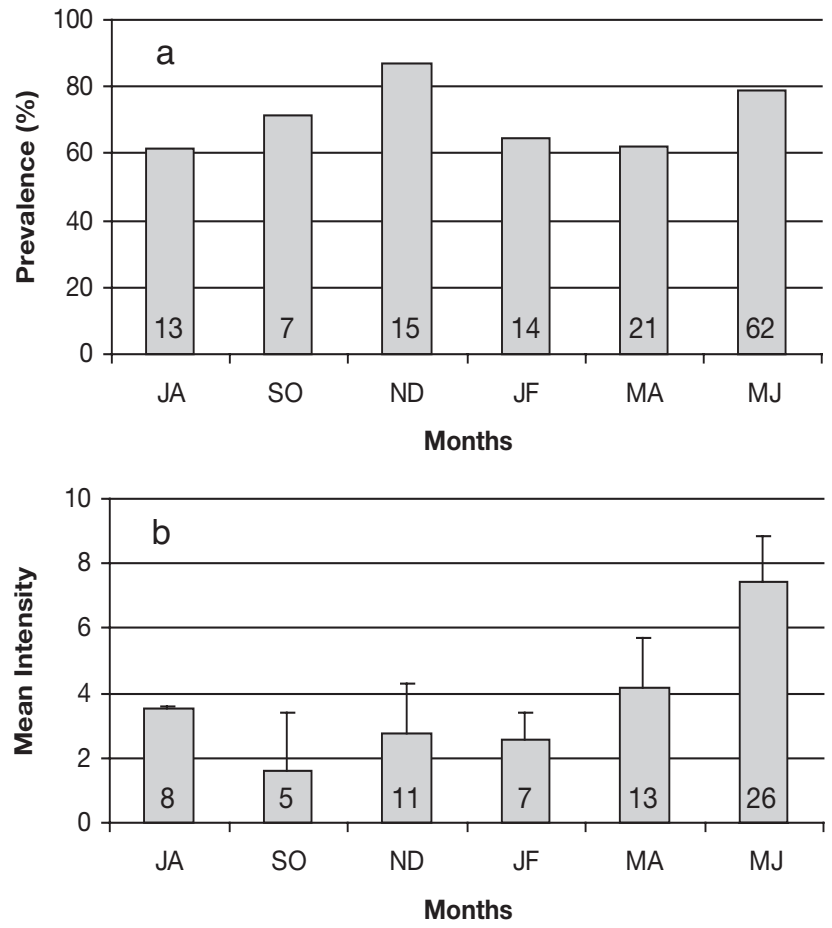

Fig. 3. Southern flounder Paralichthys lethostigma infected by adult female Margolisianum bulbosum. (a) Prevalence and (b) mean intensity (female nematodes per parasitized fish) of infection as a funtion of seasonality (in 'waves' of 2 mo). JA: July and August; SO: September and October; ND: November and December; JF: January and February; MA: March and April; MJ: May and June. Numbers inside bars are sample sizes

female worms was exactly $175 \mathrm{~mm}$ TL. No significant effect of size, age or gender of flounders for either prevalence or mean intensity $(p>0.05)$ was detected when the lowest size class containing no infected fish was excluded from the analysis. While there was also no significant effect of water temperature or salinity on either prevalence or mean intensity, there was a significant difference in prevalence, which varied in a series of waves over the year, with the highest value in November and December (86.7\%) and the lowest in July and August (61.5\%) (Fig. 3a). Low prevalences were also noted during the January through April waves (64.3\% for January and February and $61.9 \%$ for March and April) (Fig. 3a). A significant difference in the mean intensity as a function of seasonality was also detected, with the highest mean intensity $(7.4 \pm 1.4)$ found in May and June and the lowest $(1.6 \pm 0.4)$ in September and October (Fig. 3b). Even though all developmental stages of the adult female nematodes were found throughout the year (Fig. 4), L females were at their highest proportion from January through June $(60.2 \%$ in January and February, 51.8\% in March and April, $52.2 \%$ in May and June) and showed a significant sharp decline in September and October 


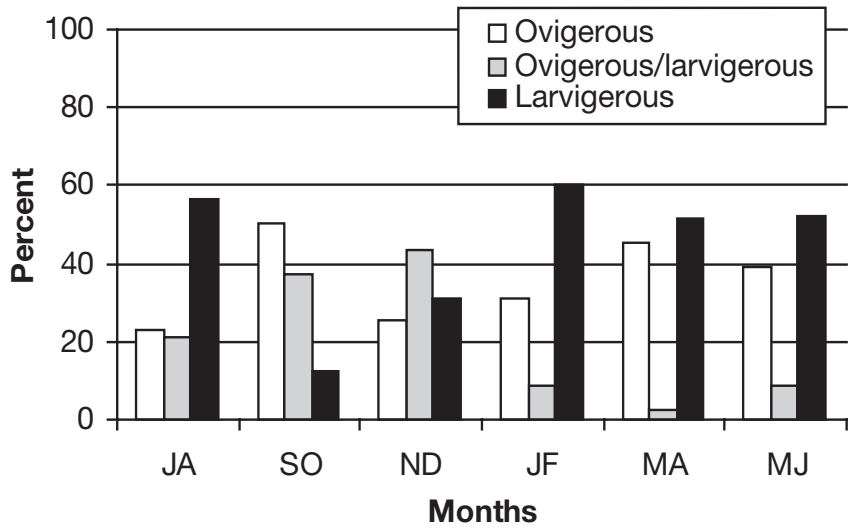

Fig. 4. Margolisianum bulbosum infecting southern flounder Paralichthys lethostigma. Percentage of different stages of maturation of adult female nematodes as a funtion of seasonality (in 'waves' of 2 mo). Abbreviations as in Fig. 3

(12.6\%). This decline in L worms was followed by an increase in November and December (31.2\%). The proportion of $\mathrm{O}$ females was lowest in July and August $(22.9 \%)$ and highest in September and October $(50.4 \%)$. This peak in $\mathrm{O}$ females was followed by a sharp decrease in November and December $(25.5 \%)$ and rebounded in January and February (30.9\%) back to a plateau of high percentage through June (45.2\% in March and April and 38.9\% in May and June). O/L females were at their lowest percentage in March and April $(2.8 \%)$, increased progressively through November and December $(43.4 \%)$, and declined sharply in January and February (8.8\%) (Fig. 4).

\section{Taxonomic status}

The philometrid nematode Margolisianum bulbosum was described by Blaylock \& Overstreet (1999) from the southern flounder Paralichthys lethostigma in the Mississippi Sound. It is not known if its occurrence on the US east coast represents a range expansion or if it has simply gone unreported in the past. Blaylock \& Overstreet (1999) introduced the new genus Margolisianum based on several factors including the presence of 8 large, paired cephalic papillae, irregular cuticular bosses except in the cephalic region, cuticularized beadlike teeth around the mouth and a separate anterior esophageal bulb. In addition to the consideration of other genera within the subfamily Philometrinae, well-reasoned support for the generic allocation was given. These authors were dissuaded from placing the nematodes within the genus Philometroides Yamaguti, 1935 because the new species lacked both the cuticular bosses within the cephalic region and the small cephalic papillae demonstrated in the latter genus. Moravec \& Van As (2001) did not consider the size of cephalic papillae to be a sufficient generic feature, and therefore placed Margolisianum in synonymy with Philometroides.

Although Moravec \& Van As (2001) agreed with Blaylock \& Overstreet (1999) that the presence or absence of cuticular bosses in females is a generic feature, the former authors appeared to ignore the importance of the distribution of these structures. Blaylock \& Overstreet (1999) stated that the cuticular bosses on their specimens appeared to be related to maturity and were most visible in living material and with scanning electron microscopy (SEM). Moravec \& Van As (2001) expanded this statement to infer that the bosses can be overlooked on some species or specimens. Although this may be true, the quality of the material and depth of analyses by Blaylock \& Overstreet (1999) clearly demonstrated the distribution of the cuticular bosses, including the absence of these structures in the cephalic region. As a result, the distribution as well as the presence of the cuticular bosses is included in the diagnosis for Margolisianum. This character supports the differentiation of the latter genus from Philometroides.

Moravec \& Van As (2001) further argued that cephalic papillae in most philometrid females were difficult to observe without SEM and that few species have been studied in such a manner. Although we agree that further study by SEM may determine the presence of small cephalic papillae in some species, such studies would not have an impact on the generic designation of Margolisianum bulbosum. The cephalic papillae present on females of $M$. bulbosum are very distinctive and obvious when studied with the light microscope. Further, the inability to observe cephalic papillae in other species or specimens does not negate the generic value of these characters for Margolisianum. Moravec \& Van As (2001) also stated that, in their opinion, the size of cephalic papillae should not be considered a generic feature. However, size and arrangement of the papillae are mentioned by Chabaud (1975) as characters of several genera in the subfamily Philometrinae. We agree with Chabaud (1975) and Blaylock \& Overstreet (1999) that these structures should be given generic consideration. We therefore recognize the taxonomic status of the genus Margolisianum and return the nematode to the designation of $M$. bulbosum.

\section{Population biology}

While few studies have been carried out on the occurrence of philometrid nematodes, most of these worms are known to have an annual life cycle involv- 
ing a copepod as intermediate host, although paratenesis may also be involved (Anderson 2000). With the exception of seasonality (waves), our results showed that the distribution of Margolisianum bulbosum in the South Carolina estuarine systems was not influenced by the abiotic factors measured. Even though the prevalence was highest in November and December $(86.7 \%)$ it was correlated with very low intensity $(2.7 \pm 0.56)$, while in May and June both prevalence $(79 \%)$ and mean intensity $(7.4 \pm 1.4)$ were at their highest (Fig. 3b). Thus, adult female M. bulbosum are most abundant in the southern flounder population in South Carolina during May and June. However, this observed variation in prevalence over the year was found to not be statistically dependent on variations in water temperature or salinity. Therefore, the observed seasonal effect on the occurrence of the adult female nematodes are most likely related to other parameters, which may include the distribution and abundance of their intermediate hosts (presently unidentified) and/or a density-dependent effect on their development, as is known to occur in the nematode Anguillicola crassus in the European eel (Ashworth \& Kennedy 1999). However, since it is known that temperature affects the development of some fish nematode species (e.g. Knopf et al. 1998), it remains possible that there is also such an effect on $M$. bulbosum, but that this is hidden by other factors. The complexity of parameters that may be involved in the maintenance of this life cycle was further reflected in the fact that all maturity stages of females were found throughout the year (Fig. 4). However, although not as clearly delineated as in other species (e.g. Uhazy 1977 , Wang 2002) (since larvigerous females were found throughout the year), our results nevertheless indicate the likely occurrence of an annual life cycle for M. bulbosum. In effect, larvigerous females make up over $50 \%$ of the adult female nematode population from January through August and only $10 \%$ in September and October (Fig. 4). Further, the overall mean intensity was at its peak in May and June $(7.4 \pm 1.4)$ and then decreased progressively to its lowest level in September and October $(1.6 \pm 0.4)$ (Fig. 3b). As indicated by the sharp decrease in larvigerous females in flounder at that time (Fig. 4), this progressive drop most probably reflects the release of larvae into the water over the summer period into the fall. In addition, the proportion of $\mathrm{O}$ females increased steadily starting in November and December and continued through March and April, with an increase in the intensity of the adult female nematodes occurring over the same time period (Figs. $3 b$ \& 4). This increase in O females may have been because the recruitment of larval nematodes begins early in the summer and continues throughout the early fall, at which time larvae are released and likely to be picked up by the as yet unidentified intermediate host(s). Further, we observed almost no O/L stages between the months of March and July although there was a concurrent high proportion of both $\mathrm{O}$ and L females (Fig. 4). In contrast, between the months of September and February, we observed a shift in the highest proportion of females to $\mathrm{O}, \mathrm{O} / \mathrm{L}$, and L, respectively (Fig. 4). These observations reflect positive temperature-dependence for development of the nematode in the fish or at least of intrautero larval development, as water temperatures in the $\mathrm{SC}$ estuarine systems increase around the month of April and decrease in October and November.

Although the larger size-class fish $(450$ to $600 \mathrm{~mm}$ TL) appeared to be less infected with adult female nematodes, the size of the host (when $>175 \mathrm{~mm}$ TL) was not a significant factor in the intensity or prevalence of Margolisianum bulbosum (Fig. 2). A similar non-significant decrease in infection was described by Wang (2002) in bullhead catfish infected with Philometroides fulvidraconi $\mathrm{Yu}, \mathrm{Wu}$ and Wang, 1993. In this case, Wang (2002) explained the apparent although non-significant decrease in infection in larger catfish by an increase in 'parasite-induced host mortality, the immune responses of the hosts, or decreased consumption of copepods'. In the case of M. bulbosum, it has been reported that the diet of flounders $>50 \mathrm{~mm}$ TL mostly comprises decapod crustaceans and fishes (Wenner et al. 1990), and thus a decrease in the consumption of copepods should lead to a natural decline in infection of large flounders. Such an occurrence would also indicate the involvement of paratenesis as a major component in the life cycle of $M$. bulbosum, as is known to be the case in a variety of other fish parasites (Morand et al. 1995, Combes 2001) since adult female nematodes die shortly after larvae are hatched. Given that our data follow the same trend as that described by Wang (2002), and that it is unlikely that large flounders eat copepods, paratenesis appears likely to play a role in maintaining $M$. bulbosum in large flounders. Such a role for paratenesis in the maintenance of the life cycle of $M$. bulbosum is further supported by the homogeneity in infection observed across all sizes of flounders (>175 mm TL). This, in concert with a high prevalence in all fish age-classes studied, also implies that larger flounders may become reinfected year after year and lack protective immunity (Uhazy 1977, Anderson 2000). Alternatively, since numerous parasite species are known to downregulate development of subsequent parasitic infections (Ashworth \& Kennedy 1999, Combes 2001), one may hypothesize that a delayed development of newly acquired $M$. bulbosum larvae in copepod-eating young flounders may occur. Additionally, hypobiosis, a mechanism often used by nematodes to circumvent 
unfavorable developmental conditions (Schad 1977, Fernandez et al. 1999), could also explain the low but stable intensities found in southern flounders across ages and sizes (Fig. 2b) as well as the combined high prevalences/low mean intensities during the winter months (Fig. 3). Confirmation of either hypothesis will require the future study of large flounders.

In conclusion, the data presented herein show a periodicity in the release of larvae from the nematodes, which strongly indicates an annual life cycle for this parasitic worm. Significantly, however, it is not known at what time over the course of the year flounders become infected. The fact that flounders $<175 \mathrm{~mm}$ TL do not harbor adult Margolisianum bulbosum does not mean that they are not infected, and it may be that they carry larvae that develop when biotic and abiotic conditions are optimal. Our laboratory is currently investigating the parameters that influence and determine the onset of infection.

Acknowledgements. This study was supported by an NOAA/ Sea Grant NA 16RG2250 to I.d.B. and by a Summer Undergraduate Research grant to C.G. from the College of Charleston. The authors thank the Inshore Fisheries Division and M. B. Maddox from the South Carolina Department of Natural Resources (SCDNR) for providing the flounders, as well as T. I. J. Smith and L. D. Heyward from the Mariculture Division at SCDNR for their support and information regarding the rearing of southern flounder.

\section{LITERATURE CITED}

Anderson RC (2000) Nematode parasites of vertebrates: their development and transmission, 2nd edn. CABI Publishing, New York

Ashworth ST, Kennedy CR (1999) Density-dependent effects on Anguillicola crassus (Nematoda) within its European eel definitive host. Parasitology 118:289-296

Blaylock RB, Overstreet RM (1999) Margolisianum bulbosum n. gen., n. sp. (Nematoda: Philometridae) from the southern flounder, Paralichthys lethostigma (Pisces: Bothidae), in Mississippi sound, USA. J Parasitol 85(2):306-312

Bush AO, Lafferty KD, Lotz JM, Shostak AW (1997) Parasitology meets ecology on its own terms: Margolis et al. revisited. J Parasitol 83(4):573-583

Chabaud AG (1975) Keys to the genera of the order Spirurida. Part 1. Camallanoidea, Dracunculoidea, Gnathostomatoidea, Physalopteroidea, Rictularoidea, and Thelazioidea. In: Anderson RC, Chabaud AG, Wilmott S (eds) CIH keys to the nematode parasites of vertebrates, No 3. Commonwealth Agricultural Bureaux, Farnham Royal, p 1-27

Combes C (2001) Parastism: the ecology and evolution of intimate interactions. University of Chicago Press, Chicago, IL

Fernandez AS, Fiel CA, Steffan PE (1999) Study on the inductive factors of hypobiosis of Ostertagia ostertagi in cattle. Vet Parasitol 81(4):295-307

Knopf K, Wurtz J, Sures B, Taraschewski H (1998) Impact of low water temperature on the development of Anguillicola crassus in the final host Anguilla anguilla. Dis Aquat Org 33:143-149

Lee CS, Ostrowski AC (2001) Current status of marine finfish larviculture in the United States. Aquaculture 200(1-2): 89-109

Morand S, Robert F, Connors VA (1995) Complexity in parasitic life cycles: population biology of cestodes in fish. J Anim Ecol 64:256-264

Moravec F, Van As JG (2001) Philometroides africanus sp. n. (Nematoda: Philometridae), a new tissue parasite of the African pike Hepsetus odoe (Pisces) in Botswana. Folia Parasitol 48:127-131

Moustakas CT, Watanabe WO, Copeland KA (2004) Combined effects of photoperiod and salinity on growth, survival, and osmoregulatory ability of larval southern flounder Paralichthys lethostigma. Aquaculture 229(1-4): 159-179

Overstreet RM, Edwards RH (1976) Mesenchymal tumors of some estuarine fishes of the northern Gulf of Mexico. II. Subcutaneous fibromas in the southern flounder, Paralichthys lethostigma, and the sea catfish, Arius felis. Bull Mar Sci 26:41-48

Schad GA (1977) The role of arrested development in the regulation of nematode populations. In: Esch GW (ed) Regulation of parasite populations. Academic Press, New York p 111-167

Smith TIJ, Denson MR (2000) Controlled spawning of southern flounder Paralichthys lethostigma: issues and progress. In: Tamaru CCT, Tamaru CS, McVey JP, Ikuta K (eds) Spawning and maturation of aquaculture species. Proc 28th US-Japan Natural Resources Aquaculture Panel. UJNR: United States-Japan Cooperative Program in Natural Resources Tech Rep 28. University of Hawaii Sea Grant College Program, Honolulu, HI, p 97-108

Smith TIJ, McVey DC, Jenkins WE, Denson MR, Heyward LD, Sullivan CV, Berlinsky DL (1999) Broodstock management and spawning of southern flounder, Paralichthys lethostigma. Aquaculture 176:87-99

Sokal RR, Rohlf FJ (1981) Biometry. The principles and practice of statistics in biological research, 2 nd edn. WH Freeman \& Company, New York

Uhazy LS (1977) Biology of Philometroides huronensis (Nematoda: Dracunculoidea) in the white sucker (Catostomus commersoni). Can J Zool 55:1430-1441

Wang GT (2002) Seasonal dynamics and distribution of Philometroides fulvidraconi (Philometridae) in the bullhead catfish, Pseudobagrus fulvidraco (Richardson). J Fish Dis 25:621-625

Watanabe W, Carroll PM, Daniels HV (2000) Recent progress in control reproduction of southern flounder, Paralichthys lethostigma. In: Tamaru CCT, Tamaru CS, McVey JP, Ikuta $\mathrm{K}$ (eds) Spawning and maturation of aquaculture species. Proc 28th US-Japan Natural Resources Aquaculture Panel. UJNR: United States-Japan Cooperative Program in Natural Resources Tech Rep 28. University of Hawaii Sea Grant College Program, Honolulu, HI, p 141-148

Waters EB (1999) Flounder aquaculture and stock enhancement in North Carolina: issues, opportunities and recommendations. North Carolina Sea Grant Publication UNCSG-99-02. North Carolina Sea Grant, Raleigh NC

Wenner CA, Roumillat WA, Moran JE Jr, Maddox MB, Daniel LB, Smith JW (1990) Investigations in the life history and population dynamics of marine recreational fishes in South Carolina: Part 1. Final Report Project F-37 Marine Resources Institute South Carolina Wildlife and Marine Resources Department, Charleston, SC 